\title{
Conceptualizing the Dynamics of Rhetorical Practice and Technological Frame in the Context of Technology Diffusion
}

\begin{abstract}
This paper examines and conceptualizes the process underlying the diffusion of a back office messaging system connecting the financial transaction activities of fund houses in Europe and banks in Taiwan. Drawing on the theoretical notions of rhetorical practice and technological frame, it develops a socio-cognitive process framework to conceptualize how the articulation of rhetorical situations and the deployment of rhetorical strategies influence stakeholders' sense-making towards a new technology. A conceptual framework is developed to enhance understanding of technology diffusion by taking into account the dynamic interplay between rhetorical practice and technological frame. We show that the persuasive power of rhetorical practices is largely influenced by (i) the rhetors' on-going advancement of local knowledge, assumptions and beliefs, and (ii) an effective deployment of a balanced rhetorical strategy to promote the technology to different stakeholders. We demonstrate that analysis of rhetorical practice helps to explain how the phenomenon of diffusion is linguistically afforded and discursively constructed into a reality.
\end{abstract}

KEYWORDS: technology diffusion, technological frame, rhetorical practice, interpretive case research. 


\section{Conceptualizing the Dynamics of Rhetorical Practice and Technological Frame in the Context of Technology Diffusion}

\section{Introduction}

The need for and importance of communication between stakeholders is key in affording the diffusion of innovations (Rogers 1995). While prior studies have provided insights into the testing and theorizing of communicational aspects of diffusion (Mann, et al. 2011; Robertson, et al. 1996; Swan and Newell 1995; Wang et al. 2013; Zaffar et al. 2014), few have challenged the assumption that values underlying a new technology can be universally communicated, understood and accepted by all stakeholders (Green 2004). One exception is the "technological frame" perspective, which emphasizes the process and dynamics involved in making sense of a new technology being considered (Allen and Kim 2005; Davidson 2002; Olesen 2014; Orlikowski and Gash 1994). Accounts using this perspective argue that the process of diffusion is essentially to socially contest and construct a shared understanding of, and thereby give meaning to, the new technology. The shared meaning given to the new technology is not something embedded in it, but emerges from it through the social interaction of relevant stakeholders as diffusion ensues ${ }^{1}$. Despite the undoubted usefulness of the technological frame concept, however, what is relatively under-emphasized in the extant literature is how meaning contestation and construction is influenced by rhetorical practice (Barrett et al. 2013; Berente et al. 2011; Huang et al. 2013).

As a distinctive type of communication, rhetoric and its enacting practice - commonly termed "rhetorical practice" - provides a theoretical foundation for the study of the instrumental use of persuasive language and discourses (Cheney et al. 2004; Sillince 2005). This theorizing is often applied in the context of implementing and institutionalizing innovative solutions and processes (Barrett et al. 2013; Green 2004; Huang et al. 2013; Suddaby and Greenwood 2005). Two conceptual components, namely "rhetorical situation" and "rhetorical strategy", form the basis of rhetorical practice (Cheney et al. 2004). A rhetorical situation symbolizes the context of rhetorical practice, while the rhetorical strategy is the approach by which rhetorical practice is exercised to achieve an intended result; in this case, with respect to giving meaning, and leading to the diffusion of, a new technology. That rhetorical practice plays a key part in the shaping of a technological frame, and a technological frame can serve as a temporal representation of rhetorical practice, notwithstanding, few accounts have thus far applied the two concepts in conjunction (Barrett et al. 2013). Doing so allows for the extension of the technological frame perspective to account

\footnotetext{
${ }^{1}$ In this sense, there is a certain emergent quality emanating from the meaning arising from the fusion of the material artifact and its perceived use, taken together - somewhat akin to the concept of sociomateriality popularized in recent times by, inter alia, Orlikowski (2007); Orlikowski and Scott
} (2008); Leonardi and Barley (2010), Leonardi (2012), and Cecez-Kecmanovic et al. (2014). 
for the impact of managerial reasoning and actions in responding to a rhetorical situation related to technology diffusion. Additionally, this integrative theoretical approach offers an analytical tool by which to examine how "frame resonance" (Kaplan 2008) is achieved (or otherwise) amongst different stakeholders. The concept of frame resonance is used here to refer to how technology champions mobilize different rhetorical practices to achieve consensus amongst stakeholders in terms of the underlying perceptions of the new technology. Analyzing frame resonance is important because a lack thereof is likely to deter or inhibit the diffusion process (Green 2004).

In this paper, we provide a synthesis of the current literature in order to develop a conceptual framework that provides a means to interpret the diffusion of a new technology. The strengths of the interpretive case study approach in examining rhetorical practice and technological frames are well documented (Olesen 2014; Pozzebon et al. 2006; Zbaracki 1998) and the rationale underlying the selection of this approach in this instance is outlined later in this paper. The setting is the financial sector, and more specifically centers on the attempt by European fund houses and IT vendors to implement a back office messaging system in order to automate mutual fund transactions between European fund houses and Taiwanese banks. This system became known to practitioners in the financial industry as straight-through-processing (STP). In this paper, we consider the diffusion of this new system from 2000, when discussions on STP began in earnest, to mid-2010, when the field study ended.

Echoing the need to incorporate rhetorical practice in the theorizing of IS research (Huang and Galliers 2011), our aim in undertaking this field study was to enhance understanding of technology diffusion by taking into account the importance and influence of rhetorical practice on technological frame and frame resonance. We trust that this research, through its application of concepts of rhetorical situation, rhetorical strategy, frame repertoire and frame resonance - and their dynamic interplay - will afford an enrichment of the theoretical landscape of technology diffusion, and potentially, of IS development more generally. Our account will also hopefully contribute to the theorization of the socio-cognitive process of collective sensemaking in the context of technology diffusion.

The paper is structured as follows. We begin by reviewing the technology diffusion literature and explaining the value of rhetorical practice in addressing the limitations of the existing literature. We then introduce the perspective of rhetorical practice as the theoretical foundation for this study. The section that follows describes the research methodology and the context in which this technology diffusion took place. Empirical findings and analysis are then presented. We conclude with theoretical and practical implications, as well as outlining few future research directions.

\section{Theoretical foundations and conceptual framework}

Largely influenced by the seminal work of Rogers (1995), current conceptualizations of technology diffusion have yielded valuable insights to enrich the theoretical landscape of user acceptance of information technology (e.g., Lanzolla and Suarez 2012; Venkatesh, et al. 2003; Zaffar et al. 2014). In the theorization of technology diffusion, two distinctive foci are clear. First, when examining technology diffusion at 
the individual level, constructs, such as relative advantage, compatibility and voluntariness of use, play key roles in shaping individuals' perception and decisions (Agarwal and Prasad 1997; Moore and Benbasat 1991; Sia, et al. 2004; Wu and Wang 2005). Second, when investigating technology diffusion at the collective level, a network's structural characteristics, such as a firm's partnerships (Hong and Zhu 2006) and buyer-supplier relationships (Iskandar, et al. 2001), and various social networks (Zaffar et al. 2014), such as professional associations (Swan and Newell 1995), together with opinion leadership (Kroes et al. 2011; Samutachak and Dekui 2012) and institutional factors (Hertwig 2012), can significantly influence both anticipated and unanticipated diffusion outcomes.

Even though communication is fundamental in shaping perceptions and decisions at individual and collective levels, what is communicated, such as the meaning of the new technology, and how the communication process is enacted amongst different stakeholders during diffusion, are rarely examined in their own right. Green (2004: 653) notes that, "discourse shapes decisions about the adoption and wider diffusion of managerial practices". He argues that rhetorical practice is the essential mechanism by which actors generate and associate meanings with respect to an innovation. Rhetorical practice is the vehicle through which actors socially construct their identities in relation to the surrounding world (Billig 1996; Morrison et al. 2013; Suddaby and Greenwood 2005). To legitimize an innovation amongst its stakeholders, rhetorical practice should provide "discursive reasons for actions" (Green 2004: 654). Moreover, as noted by Sillince et al. (2001: 1422), argumentation and justification behind an IT investment decision is politically charged and highly context dependent. ${ }^{2}$

Our main theoretical assumptions about how people shape their acceptance or rejection decisions in relation to a new technology are related to rhetorical practice, as described in the work of Cheney et al (2004). In their view, rhetorical practice through social interaction "deals with contingencies, uncertainties and ambiguities" (ibid: 82), and consists of two related elements: the articulation of the rhetorical situation and deployment of the rhetorical strategy. Cheney and colleagues use this concept to emphasize the relational nature of rhetorical practice in contrast to that of agenda setting: conceiving rhetoric as a discursive display that depends solely on the skills and abilities of the rhetor - the person who initiates the rhetoric (Eccles, et al. 1992). For them, rhetorical practice is a sense-articulating and meaning-making practice by which shared understanding of and consensus regarding the situation being encountered by both rhetor and audience is socially constructed, negotiated, accepted, and in many cases, rejected. Beyond its socially constructed nature, the Cheney framework has the virtue of integrating different insights from other prominent researchers who have focused on rhetorical practice in relation to the creation and contestation of shared meanings, such as Bitzer (1980); Crable and Vibbert (1986); Fairclough (1989); Czarniawska-Joerges (1994), and Weick (1995). The rationale behind our choice of their account of rhetorical practice as a basis for our synthesis of

\footnotetext{
${ }^{2}$ Sillince and his colleagues used the institutional changes within the UK National Health Service as an example of how rhetorical practice acts as a force in altering participants' perceptions towards the legitimacy of a proposed solution.
} 
this literature is twofold. First, their account focuses on how sharing understanding and consensus are contested and constructed through the day-to-day practices of relevant stakeholders, rather than on the pure linguistic meaning of the deployed rhetoric. Second, due to their ontological positioning, their account emphasizes the importance of social-cognitive processes that are fundamental to the theorization of collective sense-making and framing (Berente et al. 2011; Davidson 2002; Kaplan 2008; Olesen, 2014). In our study, this has particular resonance since one of our main theoretical premises is that, even though values afforded by the new technology are key decision criteria, the socio-cognitive process (such as a participants' framing and sense-making), also plays a fundamental role (Davidson 2002; Kaplan 2008; Mishra and Agarwal 2010; Olesen 2014; Orlikowski and Gash 1994; Weick 1995).

For a rhetorical practice to be persuasive - in the context of this study, for the vendor to influence the banks' commitment to the new technology - a rhetor needs to construct the "rhetorical situation" and devise and deploy a rhetorical strategy to present their rhetoric to the target audience. According to Cheney et al. (2004), a rhetorical situation reflects the rhetor's understanding and interpretation of the contingencies and the solutions that are proposed to address them. Referring to the typology of Benford and Snow (2000), the contingencies are a type of "diagnostic frame", while the solutions symbolize "prognostic frames". Kaplan (2008) argues that diagnostic and prognostic frames are important in their own right, but that it is equally important to ensure a level of congruence between the two. According to Sillince (2005, p. 608), congruence refers to the level of "fit among contingencies, structure and strategy". In other words, a good diagnosis of the contingency can fail to achieve its persuasive value if a poor solution results, and vice versa. Thus, congruence is not just a quality relevant to the rhetorical situation, but also to the rhetorical strategy (Sillince 2005). Further, for a rhetorical strategy to reach a desirable level of congruence, the rhetor needs to blend and balance two complementary strategies, namely, strategies associated with differentiation and with integration (Sillince 2005). Sillince argues that a differentiation strategy aims to surface and address localized assumptions and differences, while an integration strategy aims to project a unified picture by which benefits can be achieved through collective actions.

The level of congruence in relation to both the rhetorical situation and the rhetorical strategy depends on the way the rhetor constructs and presents them, as well as on how the audience perceives and processes them. In addition to the rhetorical situation and strategy presented by the rhetor (what), and the means by which they are presented (how), stakeholders draw on their past experiences, existing expertise and understanding - "frame repertoires" in Kaplan's (2008) terms - to evaluate the rhetoric. Kaplan argues that, when the levels of congruence are well aligned with the audience's frame repertories, "frame resonance" occurs. Thus, when the level of frame resonance is high, stakeholders are more likely to commit. In contrast, when the level of frame resonance is low, stakeholders are mostly likely to defer their decision or reject the technology altogether. Information about these decisions, regardless of whether they accept, reject or defer, is collected by the rhetor to determine whether further rhetorical practice will be required. As shown in Figure 1, rhetorical practice occurs in a recursive manner. In Figure 1, we use the arrows to indicate (i) a processual view of rhetorical practice and (ii) how the result of a rhetorical practice 
can influence rhetor's approach towards their audiences. Initially, the rhetor puts forward his/her view of the rhetorical situation to the intended audience, based on the rhetorical strategy that is perceived to be appropriate. The degrees of congruence, both in the rhetorical situation and the strategy, affect the level of frame resonance on which the audience bases their decisions in conjunction with their frame repertories. Once commitments are made, stakeholders can become a source of "rhetorical resource" (Jarzabkowski, et al. 2010) on whom the rhetor can draw, in particular, initiating a new rhetorical practice with a view to persuading non-adopters. However, under the condition that the rhetors fail to persuade the adoption decision, they might continue another process of rhetorical practice by potentially altering different elements previously deployed. The following section outlines how Figure 1 is operationalized in our research process.

$<<$ Insert Figure 1 here $>>$

\section{Methods}

Our study employs an interpretive case approach (Pan and Tan 2011; Walsham 1995). The strengths of interpretive case studies are well documented ${ }^{3}$ (Davidson and Chismar 2007; Pan and Tan 2011), in particular for investigating meanings and reality that are socially constructed (Walsham 1995), embedded within natural settings (Orlikowski and Lacono 2001), and intertwined with practices and consequences of participants' social actions (Pawlowski and Robey 2004). Due to the need to examine the phenomenon of diffusion over time (Rogers 1995), our research design is longitudinal in its orientation, in particular to understand how changes in rhetorics and their related practices unfold. Nevertheless, we acknowledge that the data collection and analysis process can be significantly shaped by the researchers' preconceptions (Walsham 1995). Thus, the concept of rhetorical practice served as a 'sensitizing device' (Klein and Myers 1999) to guide the interpretation of stakeholder actions and events throughout this study.

\section{Research context: The Taiwanese offshore fund industry ${ }^{4}$}

Since the strong economic growth period of the 1980s, the Taiwanese government began a series of financial reforms to facilitate the growing demand for accessing overseas investment opportunities. In 1983, the government amended the Securities and Exchange Act to allow the offering of domestic mutual funds by local banks, securities brokers and securities investment enterprises. Since the 1990s, several economic and political factors contributed to the emergence and growth of offshore funds in Taiwan, as offshore funds appeared to be a safer investment alternative compared to the domestic stock market. To this day, offshore funds continue to attract the interest of investors and the active promotion of offshore alternatives on the part

\footnotetext{
${ }^{3}$ Different approaches and paradigms for IS research are explored in, for example, Galliers et al., (2007).

${ }^{4}$ See for example: 'Taiwan mutual fund history' http://www.epochtimes.com/b5/2/9/8/n214028.htm and 'Mutual fund product and business practices' (Fubon Investment Trust Company, 2007).
} 
of financial advisors.

\section{Data collection and analysis}

Field data collection took place between 2008 and early 2010, during which time we reviewed historical documentation covering the whole decade. We conducted 50 individual face-to-face, semi-structured interviews with thirteen distributing banks (28 interviews), three fund houses (6 interviews), three global software providers (11 interviews), and two domestic IT vendors (5 interviews). Bank and fund house interviewees were those directly involved in business areas where STP could or have been used in their respective organizations. For example, our interviewees from the bank were managers from the trust department or the IT department. At the outset of the data collection process, we contacted the bank managers through the introduction of the global STP provider. Additionally, by attending fund automation conferences, we were able to identify and get to know potential interviewees. To secure interview access, we agreed to provide feedback arising from our field observations at an industry workshop and various meetings. Typically, interviews lasted more than 90 minutes and were tape-recorded and then transcribed. All interviews were conducted in Mandarin, except for those with the global STP providers and fund houses, which were conducted in English. Those interviews conducted in Mandarin were translated into English following transcription. Research notes were taken during each interview, following on-site observation, and as a result of informal dialogue. In addition to individual interviews, we participated in meetings and conferences, including four Asia Fund Automation Consortium (AFAC) meetings where managers from the fund houses met and discussed the STP strategy. We also attended a number of fund automation conferences and one industry workshop. Additionally, we accumulated a wealth of documentary data, including e-mail correspondence with practitioners; letters between practitioners regarding the establishment of a consortium; conference presentation materials; meeting minutes; newsletters, and press releases about STP training and diffusion.

Our data analysis consisted of four steps, notably summarizing, clustering, displaying and comparing the collected data (Easterby-Smith et al. 1991) by applying the conceptual framework proposed earlier. Two of the researchers went through each interview transcript, document and field note to summarize the key points. The summarized data were then clustered. The clustering process afforded us the means to analytically identify areas of data leading to the surfacing of key themes. Based on Figure 1, we displayed the key events chronologically (Table 1). After the underlying storyline was established, we reviewed our data once more to ensure that we had not missed out any key points vital for our conceptualization.

\section{$<<$ Insert Table 1 here $>>$}

The chronological display of the three phases led to the identification and further analysis of three rhetorical situations. These three situations represent three distinctive sets of rhetorical practices within which different combinations of rhetorical situations and strategies were deployed by the rhetors to influence STP diffusion. Synthesizing different stakeholders' views and responses to each of the three rhetorical situations and comparing how they evolved over time provided the basis for us to assess the 
degree of congruence (or lack thereof) amongst the local banks. The final step in the research process was to validate our findings by independent review of the empirical data by each of the co-authors and via feedback obtained through our interactions with practitioners at the workshop and other meetings.

\section{Case findings}

The following case narrative describes the phases of STP diffusion in the Taiwanese banking industry during the period under study. As noted, we do so through the analysis of the three rhetorical situations that we identified, utilizing the theoretical framework (summarized in Figure 1). That is, for each rhetorical situation, we examine (i) how a group of rhetors (i.e., fund houses and global vendors) developed their diagnostic and prognostic frames, and articulated the corresponding differentiation and integration strategies; (ii) the audience's (i.e., the Taiwanese banks involved) frame repertoires, and (iii) the degree of congruence and frame resonance and its impact on the progress of (STP) diffusion. The transition from one rhetorical situation to another symbolizes the development of a new rhetorical situation and the associated rhetorical strategies to address the outcomes that rhetors failed to achieve previously. These transitions serve as useful indicators of the occurrence, or the lack thereof, of the Taiwanese banks' frame resonance. The lack of frame resonance is particularly salient in explaining situations where some of the local banks were able to understand the functionalities afforded by STP, but did not fully accept the benefits projected by the rhetors. We now articulate the introduction and diffusion of STP during the first decade of the 2000s in the three phases - rhetorical situations outlined above.

\section{Phase one: 2000-2003 - Resistance}

The development of an offshore fund industry in Taiwan led to challenges with respect to the existing manual fund processing practices. The growth in fund size, together with the volume of transactions, became a major driver in the push for automation. With mounting volumes and increasing turnover, the Asian fund offices were facing pressure from their European headquarters to automate their processes through STP, primarily for two reasons. First, STP was seen as a means of reducing the need for manual intervention and avoiding human error (e.g., missing faxes or mistakes due to unclear hand-writing). As one fund house manager put it:

“... it's difficult sometimes to tell the difference between the number 0,6 and 9. And it's very easy to receive a paper that's smudged. In these cases, a lot of time will be wasted in communicating and confirming the content of the fax."

Second, the fund houses perceived STP as facilitating improved information processing efficiency and achieving cost savings in the distributing banks. One of the fund house managers indicated that:

"In Europe, the majority of funds are [managed] in Luxemburg and Dublin. [Here], labor is expensive and in short of supply. Therefore, STP is a good way to increase efficiency and save costs. For us, to implement STP in Asia costs nearly nothing technology-wise since our European office already has the technology and the capability in place." 
Thus, from the early 2000s, various fund houses began to contact their respective distributing banks about the possibility of implementing STP. As an example, the fund houses' Asian offices in Hong Kong started working with AutoP (a pseudonym given for confidentiality reasons) around this time. AutoP focuses on global market infrastructure products that standardize financial messages and has a regional office, also in Hong Kong. AutoP had been working with the global fund industry with a view to gaining agreement on ISO $20022^{5}$ standards and market practices for mutual funds since the early 2000s. Many banks in Taiwan are AutoP clients. Given this already established relationship, AutoP believed that securing Taiwanese banks' commitment to STP should be straightforward. The rhetoric put forward by AutoP placed a strong emphasis on the role and potential of STP as the solution for service transformation. One of the AutoP managers informed us that:

"In Taiwan, you have about 38 banks. For retail wealth management, you need to have a good revenue stream, and save costs. STP is a long-term winner here. [But] in Taiwan, we have learnt that cost saving is not the ultimate argument for implementing STP. [It's more to do with] client services ego. For example, each bank wants to be become a Citibank in wealth management. You won't achieve that if you're still manually processing your fund service. The idea is that you catch up or fall behind".

The approach taken by AutoP was to target the distributing banks individually by conducting company visits. As the Regional Head of AutoP put it:

"In the beginning, you need to start with an individual company visit. You can then understand how each company works, and who's responsible for what decisions, and [who has] power. You need to get the right person to participate in the working group, otherwise, it won't work."

While AutoP and the fund houses had been actively promoting STP, reactions from the bank managers we interviewed suggested that there were still concerns, ranging from a lack of sufficient justification to inertia in introducing changes. For instance, a bank manager noted that:

"Our bank ... [enjoys] strong competitive advantage [through] low capital costs ... Because of our low capital costs and unique customer groups, we have no urge to implement STP. Banks are in the business of selling credits, so conservative thinking is embedded in top management's mentality. [There's] no desire to compete to be number one in the market. Secure operational stability is the priority".

Despite three years' effort on the part of AutoP and the fund houses, and for the kind of reasons identified above, there had been not a single commitment made by any of the distributing banks to accept STP.

\footnotetext{
${ }^{5}$ http://www.iso20022.org
} 


\title{
Phase two: 2003-2006 - Reassessment and changed tactics
}

The lack of commitment to STP during the first phase called for a reassessment and change in tactics on the part of AutoP and the fund houses. As one of the fund house representatives commented:

\begin{abstract}
"There are several issues here. For instance, the head of the trust department doesn't want to spend money. They're on a cost cutting strategy; they're even taking out ATMs! The mentality right now is to minimise existing costs. But one day I believe the bank will be caught out as volume grows back again. They'll lose customers because others are ahead in providing a better value proposition to customers".
\end{abstract}

As a result, AutoP began launching a series of activities to promote STP, including the formation of the Taiwan Fund Operation Group (TFOG) in 2003, and the AutoP Fund Masterclass conference in 2004. The main rationale behind forming TFOG and organizing the conferences was to target key banks in a concentrated effort to market STP. In addition to the conferences, TFOG was formed with the agenda to "discuss operational issues, business cases, and market practices for the Taiwan market". In preparation for the conference series, AutoP identified the banks that they thought might be interested in STP from their client list and also contacted the relevant professional associations, including the bank association, the securities investment trust and the consulting association. Participation was free. The conferences placed considerable emphasis on promoting the benefits of STP. The key selling points included, primarily, cost-efficiency, standardization and risk reduction. To strengthen the message, AutoP invited speakers from Europe, Singapore and Hong Kong.

Thus, AutoP, as well as some of the fund houses, focused on involving the leading banks and positioning STP as a fashionable innovation that leading - "progressive" Taiwanese banks should embrace. Thus, instead of targeting all the distributing banks in Taiwan, AutoP adopted a more selective approach, inviting only a small number of banks to form TFOG. The idea was to have some of the leading banks set the example, with other banks hopefully following suit. Commenting on AutoP's approach, one of the bank managers outside TFOG told us:

“... AutoP was very selective as to which companies they picked to participate. The salesperson started by talking to each of the distributing banks. He listened to the views [expressed] and then he picked the favourable ones."

In addition to AutoP, the fund houses were keen to see banks in Taiwan implementing STP as already noted. In addition to actively participating with AutoP and TFOG in discussions regarding transaction standards, seven fund houses decided to form the Asia Fund Automation Consortium (AFAC), in 2006. A statement from AFAC indicated that the consortium is "committed to driving the STP initiative within the Asia Pacific fund industry". The significance of forming AFAC was explained by one of the members as follows: 
"Having seven fund houses together, we're very powerful in dictating the standards about automating fund processing in Asia. As for the latecomers, they'll just have to follow the standard. With standardization, technology testing with fund house becomes a process, not a pain".

In order to persuade the first bank (called Innovbank for the purposes of this case study) to implement STP, AutoP and its local IT partner provided preferential treatment as an added incentive. This was expected by Innovbank and included the development of a more customized STP system in line with the bank's particular requirements. In late 2004, AutoP and Innovbank began to discuss the details of implementation and transaction data standardization. However, it was not until 2006, when Innovbank's STP went live.

Although the diffusion of STP took much longer than AutoP had anticipated, their efforts, together with those of the fund houses, helped to enhance local banks' awareness of the importance of automation in general terms, and STP's role more specifically. In contrast to the previous phase, where the understanding of STP and its potential benefit was very limited, during this phase there was increasing awareness of STP and improved capability on the part of local bank managers to evaluate its suitability.

\section{Phase three: 2006-2010 - Following the leader but changing the story}

STP going live at Innovbank in 2006 was an important milestone - a turning point in influencing other banks to consider the system. By the end of 2010, there were five banks - including Innovbank - that had implemented STP. All were using the system sold by AutoP. The second case was in 2007, two banks went live in 2008, and one at the beginning of 2009. During this phase, AutoP and the fund houses continued their efforts to promote STP at conferences and in client visits. However, one of the most distinctive changes in AutoP's approach was to invite the IT director of Innovbank to become an advocate, influencing other banks to implement STP. Innovbank's IT director was not only a regular speaker at the conferences but also a main source of insightful experiences regarding the implementation of STP.

Having a highly respected local bank adopting STP was crucial in persuading other banks to follow suit. First, STP was perceived as a result to be suitable for the local context, having been properly tested and tailored for the Taiwanese market. This was viewed as making implementation easier, as common formats and standards had thereby been created. Also, time taken to test the product was seen to have been reduced, given the on-going improvements that had occurred at Innovbank. Second, the local IT vendor, given its experience with Innovbank, had developed in-house know-how in implementing STP, thereby shortening the learning curve. Third, the Innovbank experience had reduced the fear of many local bank managers: they would no longer be seen as a "guinea-pig", and the IT executives concerned had a readymade case to help them in gaining support from senior management.

Notwithstanding that the feasibility of STP having been demonstrated by Innovbank, securing the support of senior management remained a struggle. For example, the IT director of NewTaiwan, the second case and main competitor of Innovbank, had been 
considering implementing STP prior to 2006. As he argued, it was not in light of the perceived benefits of STP that gained the support of top management. Rather, it was Innovbank's implementation that triggered NewTaiwan to follow:

"For us, efficiency is everything. Clearly, being a private bank, competitiveness and quick response to market change, such as the use of STP by our competitor, are our main concerns."

The third case, Leadbank, was the only one amongst the five that had the scale and volume to potentially justify the cost of implementing STP. Nevertheless, Leadbank managers indicated that the successful implementation of Innovbank had helped to show to their top management that STP was a relatively risk-free solution:

"It was around the first quarter of 2008, when the fund business was blooming that our department started to realize the need for automation. Besides, there's always a need for every department to set their annual goal for process reengineering and new business development; STP ... came in to fulfil that purpose. We were lucky to initiate the project when business was still good at the time ... Having a local bank using STP, we were able to show our boss that STP was a risk-free solution ... [and] things went quite smoothly during the implementation."

The rhetoric mobilized by the fourth case was very different to the rhetorics presented by the rhetors and other organizations. One of the managers from the fourth adopting bank, Pearlbank, indicated that:

"With our traditional emphasis on international trade, IT was rarely on the top management's agenda. To get the go-ahead, the business case for STP was presented as being a critical element in enabling our internationalization strategy."

As the last of the five cases, managers in the trust department of Earthbank suggested that they had been waiting for a number of years for the "right time" to put forward the business case for STP to the bank's top management. The "right time" came as the result of a handling error. According to the STP project manager at Earthbank:

"In one incident, an order of NT $\$ 4$ million was mistakenly put as $€ 4$ million by one of our staff. Based on the exchange rate between NT\$ and $€$, we're talking about 45 times the difference in value! Even though the error was spotted later by another department, we knew that it was the type of error we couldn't afford to make. Clearly, it won't be the only type of error that can happen to us."

The business case proposed by the Earthbank's trust department had thus shifted from the technological features and economic benefits of STP to the importance of avoiding human error. As with the other banks, and as noted by the Earthbank project manager:

"Justifying the cost-benefit of STP can rarely make financial sense ... Most top managers might not necessarily fully appreciate this [human error] 
justification. They are, though, aware of the need to avoid operational risks, which can cost far more to correct."

Despite the fact that the process of implementing STP had become less complicated than anticipated, the benefits arising from the system were also perceived to be more limited than that which had been promised. As one manager put it:

\begin{abstract}
"Transaction flow is still the same - not much difference has occurred. We ... only need to make the order, and for the rest we rely on the system. However, not all fund houses are 'live', so we still need to handle the paperwork for those who haven't automated. [Having said that, while] transaction flow might not have changed much, time saving is the biggest benefit".
\end{abstract}

According to many of the bank managers we interviewed, the pricing structure of STP remained the most critical bottleneck, not just for banks currently using STP, but also for those that were still considering of implementing it. The STP pricing model was being continuously negotiated between AutoP and the various banks - even with some of the existing adopters - notwithstanding AutoP's unwillingness to compromise on further price reductions. Given these kinds of concerns, and as already noted, there were just the five organizations implemented STP in Taiwan as our study came to an end in early 2010.

\title{
Discussion
}

In this section, and in line with the theoretical framework depicted in Figure 1, our discussion focuses on an interpretation of the rhetorical situation and rhetorical strategies identified in each phase.

\section{Phase one - Resistance}

Although promoting the diffusion of STP had started before 2000, more systematic efforts came into being when the fund houses joined forces with AutoP to engage the local banks in rhetorical practice early in 2000. At this point, diagnostic frames commonly shared by the fund houses were reflected in their encounter with increasing transaction costs and low levels of process efficiency, due to the need for human intervention in the then trading process. Unsurprisingly, encouraging local banks to embrace STP as a means of cutting costs and improving process efficiency characterized the fund houses' collective prognostic frames. The fund houses' rationale for selecting AutoP as the provider of STP resulted from the existing relationships AutoP had with the local market. From the perspective of AutoP, the rhetorical situation was not so much about exploring new relationships with local clients. Rather, the emphasis was on disseminating the benefits of STP to secure the local banks' commitment.

Initially, STP was projected by the rhetors as a means of automating the fund trading process, or at least key parts of the transaction. Even though the rhetoric of AutoP and the fund houses in highlighting the potential of STP had been well understood by many of the distributing banks, very few were fully convinced about this as a justification for considering the system. This lack of congruence was illustrated not only in the rhetorical situation articulated by the rhetors in justifying the need for STP, but also in the rhetorical strategy deployed. For instance, fund houses had commonly 
perceived the problems of high cost and the lack of operational efficiency as being caused, in the main at least, by the absence of automation in Taiwanese banks. Hence, their intended solution was simply to convince local banks to implement a system (STP) that would provide a means of automating the process. The differentiation strategy deployed by AutoP, and endorsed by the fund houses, yielded very little in the form of intended results. This was partly related to local banks' perceptions of AutoP as the provider of FOREX messaging services, which are typically used for the trading of foreign currency, as well as AutoP's lack of understanding of the banks' generally negative attitudes towards diffusing new practices or technologies.

Three distinctive yet interrelated areas are particularly relevant in explaining the lack of frame resonance between the rhetors and the distributing banks. First, when STP was associated with automation, the persuasive power of the automation rhetoric was relatively weak so far as the local banks were concerned. As demonstrated, with regard to automation, what seemed beneficial to the banks was the saving of man hours. In a society where labor costs are trivial compared with the cost of acquiring and using STP, it was not so surprising that the persuasive power of the automation rhetoric was far too weak to secure support: none of the distributing banks had managed to win a business case based on the automation argument, even during the later phases. Second, even though many of the local banks understood the potential afforded by STP, few considered the fund houses' collective agenda to reduce their operating costs as something that they should address urgently. Third, many bank managers expressed concerns about their own organizations' risk-avoiding cultures and lack of interest in initiating what were seen as IT-related changes.

Although no bank in our study had rejected STP out of hand during the first phase, no bank had decided to implement STP either. Notwithstanding, the rhetoric of automation in relation to STP did have some impact on the local banking community. During this first phase, the rhetoric of automation was attractive to many back office managers who were struggling with the ever-growing volume of fund trading transactions. For them, automation was a concept that was most relevant and urgent. However, the rhetorical practice behind STP did not provide them with the level of frame resonance necessary to gain commitment from their senior management. This is reflected in the cases of implementations, as well as some of the banks which decided not to go ahead with STP. Indeed, their continuing interest and representations served as a catalyst for AutoP and the fund houses to rethink and rework their rhetorical practice, as this phase unfolded.

During the latter part of this phase, we saw that the diagnostic and prognostic frames that the rhetors were articulating drew heavily on European experiences and perspectives in relation to STP practices. This led to the enactment of a differentiation strategy as a key aspect of the rhetorical situation. In particular, by blaming inefficiencies in the transaction process as being simply due to the absence of automation in Taiwanese banks, it was understandable that the differentiation strategy failed to gain sufficient support from and congruence with the local community. The lack of consensus amongst local banks concerning STP proved to be too much of a barrier for STP diffusion to actually occur at this stage. It is clear that the rhetors' differentiation strategy was based on a perceived value of STP that was centered in 
the European context, but failed to take into account the local business agenda and priorities. This led to a very low level of frame resonance between the European fund houses and the Taiwanese banks, and as a result, no commitment to implement was observed during this period.

\section{Phase two - Reassessment and changed tactics}

During the second phase, there was considerable evidence to suggest a switch in rhetorical practice to address the lack of congruence and relatively low level of frame resonance that characterized the first phase. The switch was reflected in the rhetors' assessment of the rhetorical situations and the modification of rhetorical strategy in light of this assessment. As reflected in the rhetors' diagnostic frames, the rhetorical situations portrayed a mixed picture. From AutoP's point of view, the lack of commitment to STP was due mainly to the limited understanding of benefits associated with STP, and partly due to the risk-avoiding culture evident in the local market. From the fund houses' perspective, limited willingness to embrace STP was due mainly to the local banks' reluctance to make financial investments for process improvements. Given that a lack of understanding with regard to STP's benefits was perceived as one of the main barriers, at least from AutoP's point of view, the prognostic frame is illustrated by the series of conferences and company visits made by AutoP and the fund houses in order to counter this rhetorical situation. Additionally, the rhetoric concerning the value of STP was also refined. In addition to its association with automation, as reflected in one of the objectives of establishing TFOG, STP was now projected by AutoP and the fund houses as a strategic tool for service transformation, which implied a higher cost to justify its value. Compared with the earlier phase, when STP was projected as a necessity for local banks to play their part in the modern (efficient) trading process, the new rhetoric injected a more nuanced view of STP, portraying the system as a means to survive and compete in the international market.

The rhetorical strategy had also undergone certain refinements during this phase. An attempt was made by AutoP and the fund houses to incorporate some degree of integration into their new rhetorical strategy. For instance, the organization of TFOG was key in reinforcing a more integrative approach amongst some of the leading banks in Taiwan than had been the case in the previous phase. By intending to use TFOG as a showcase for STP, the underlying rhetorical strategy was about using the selective-integrative approach amongst the elite banks in the local market. Such an approach was designed to project STP as an exclusive solution for only the selected leading banks in Taiwan. However, what seemed to contribute most significantly to the level of congruence in rhetorical strategy, for the local banks not involved in TFOG as well, was the formation of AFAC. Given that the full potential of STP could only be achieved once the number of users grew, the formation of AFAC held certain symbolic importance to all concerned. In addition to the fund houses' willingness to work together towards standardization, it also showed that improving the efficiency of fund trading was not just the problem of the local banks, but all those involved in the trading process.

Referring to Figure 1, we see that the growing balance between the enactment of the differentiation and integration strategies combined contributed to increased 
congruence amongst some of the local banks. Even though many banks found themselves to be still unable to commit to STP during this phase, cases, such as Pearlbank and Earthbank, had become more aware of what might be the barriers in their own organizations. The improvement in frame resonance was particularly visible regarding considerations as to how STP could be introduced, if certain conditions (e.g., setup and running costs) could be improved. In comparison to the previous phase, during which STP's usefulness and diffusion feasibility remained in doubt, there were growing feelings of acceptance towards of the system, and on-going efforts on the part of local bank managers to champion STP in their organizations. During this phase, there was also a clear split between the local banks that were actively considering STP and those that were not, as reflected in the participation of TFOG. Given the costs involved in implementing and running STP, many argued the business case was still not justified, while others began to relax their opposition. In either case, while expensive, STP had become a better-understood and appreciated technology. The implementation of STP in Innovbank was clearly a turning point, especially in the generation of additional rhetorics from the perspective of the leading distributing banks, as we saw in phase three.

\section{Phase three - Following the leader but changing the story}

The third phase not only saw changes in rhetorical practice, but also in the number of rhetors involved, with the active involvement of the IT Director of Innovbank. One of the themes reflected in AutoP's and the fund houses' diagnostic frame during the second phase was the local banks' general concern about not becoming a "guinea-pig" of STP. The emergence of a local bank that had implemented STP clearly helped in overcoming such fears. The significance of including Innovbank into AutoP's rhetor team was more than merely a demonstration of the feasibility of STP diffusion. It generated a rhetoric concerning the diffusion of STP from the viewpoint of a local bank - not only that of foreign institutions, such as AutoP and the European fund houses. This marked a crucial shift in the diagnostic frame of AutoP and the fund houses. Instead of continuously promoting the benefits of STP as a means of increasing efficiency in a global context, they approached the rhetorical situation more in terms of a local affair, offering a local solution. Having Innovbank on-board to share their experiences with other banks helped not only to legitimize the prognostic frame of AutoP and the fund houses, but also to achieve a higher level of congruence with the diagnostic frame.

Capitalizing on Innovbank's case, AutoP and the fund houses also modified their rhetorical strategy to ensure a more balanced approach than in the previous two phases. What seems to have been particularly convincing during this phase was that STP had become a tested solution that worked in the Taiwanese market. The localized rhetorical strategy began to generate more positive responses from local banks. With Innovbank as the first case, other banks perceived the risks of being a 'guinea pig' to have been reduced. The sharing of Innovbank's experiences within the local community evidently stimulated more adoptions. Not only were there a growing number of adopters, however: the general level of understanding of STP and of the potential implications of implementation also improved. As a result of the higher degree of congruence in rhetorical practice, there was not merely a higher degree of frame resonance (given the banks' understanding of STP), but also a stronger 
commitment towards actual commitment. Even for the banks which decided not to implement STP, it was clear from the case narrative that their decisions were no longer related to a lack of understanding of what the solution could or could not afford. Indeed, several IT managers and heads of trust departments were highly interested in STP. However, in several cases, they were also very aware that implementing STP was unlikely to be supported in their own organizations, mainly due to cost considerations.

Without Innovbank's case, the story of STP diffusion in Taiwan could have been very different. The emergence of a first case was a significant tipping point in the diffusion of the technology, as evident in the other four banks. Equally important, however, was the presence of different rhetorics to which the followers were exposed. In other words, while AutoP and the fund houses were the key early contributors to the STP discourse, the richness of the rhetoric was added to and revised by Innovbank and the later cases - and even those decided not to implement STP.

The creation and refinement of the rhetorical repertoire in the local fund trading community served two essential roles in enhancing the level of frame resonance shared by local banks. First, the repertoire became a source of inspiration for later implementation cases. Having said that, to successfully argue the case for implementation, it is not just the content of the rhetoric that matters. It is also about how the rhetorics are put together to gain support from top management. The storytelling within the network of banks was a crucial mechanism to achieve this support. Second, the repertoire can be seen as a window that reflects the changes in understanding of, and the agenda relating to, STP. For instance, when AutoP first introduced STP to the Taiwanese market, the key selling points emphasized aspects of cost efficiency, standardization and risk reduction. Even though the underlying concept of standardization (and its importance to a distributing bank's operation) was addressed by AutoP from the outset, few banks were fully aware of the implications. The experiences of the five cases contributed - partially at least - to a growing awareness of the importance of standardization and integration throughout the local industry. The dissemination of this awareness is reflected in later discourses that had clearly moved on from the rhetoric of automation to a more sophisticated justification to implement in terms of, for example, ensuring operational excellence and managing risk. Growing understanding of STP is not just about what STP can do but also about what it cannot do. Given that there are 71 offshore fund houses offering 976 types of offshore funds to Taiwanese investors (as of November 2009), to connect all the fund houses with all the distributing banks is clearly far too ambitious for any single vendor to consider.

In sum, we have noted changes in the frame repertoires of the rhetors and their audiences arising from the on-going interaction and refinement of rhetorical practices during the first two phases we identified. These symbolized not only the rhetors' efforts in addressing the lack of congruence between the rhetorical situation and strategy, but also led to an important increase in the degree of frame resonance. The turning point may be seen as Innovbank's implementation of STP, since its involvement led to the diagnostic and prognostic frames becoming more relevant to the local financial community. Having gradually come to appreciate the varying 
attitudes of the local banks, the rhetors also began to balance the use of a strategy of differentiation and integration. This alignment between the rhetors and their audience (i.e., AutoP and the fund houses vis à vis local banks) resulted in the sharp increase in STP diffusion, albeit amongst a small number of leading banks, within a relatively short period of time between 2008 and 2009.

\section{Conclusion and Implications}

Our findings suggest that improving our understanding of the rhetorical practice amongst different stakeholder groups is one approach to increasing our understanding of the complexities involved - both practically and theoretically. Our study is not without limitations of course. Generalizability in a statistical sense (Walsham 1995) is lacking as with all interpretivist studies. Nevertheless, we have actualized the essence of "generalizing from description to theory" (Lee and Baskerville 2003: 235) in this particular setting. We now specify our four distinctive yet interrelated theoretical contributions.

First, drawing on the perspective of rhetorical practice permits us to consider the discursive quality of sense-making by which meaning and interpretations around the introduction of a new technology are collectively developed by stakeholders as negotiated rhetorical practice. Indeed, the very notion of rhetorical practice - or practices - leads us to consider future research that brings together the rhetorics associated with notions of strategy-as-practice and micro strategizing in the context of information systems strategizing and information technology diffusion, along lines similar to those that were recently argued by Peppard et al. (2014) and Whittington (2014).

We believe that this novel approach to sense-making in general, and technological frames more specifically, is particularly relevant when interpreting situations where decision makers' understanding of a technological solution (in this case, STP), was initially at least - very limited. It is this lack of understanding about the technology that gave the vendors and other stakeholders (e.g., the fund houses), room to be creative in their rhetorical practice, given that they were dealing with a blank canvas.

Second, our conceptual framework allows us to capture and conceptualize the process and patterns by which frames are formed and shifted through the influence of rhetorical pursuits. As noted in prior studies (Davidson 2002; Olesen 2014; Orlikowski and Gosh 1994), technological frames can limit opportunities and alternative options available to actors, as these frames serve as filters in the processing of information. Our findings recognize the limitations imposed by these technological frames. Nevertheless, it is also clear from our findings that some stakeholder groups were able to intentionally modify and reshape these frames to achieve their intended outcomes. By taking into account these linguistic considerations, we are able to enrich the existing theorization of the socio-cognitive approach, in particular with regard to the notion of technological frames, by adding the influence of rhetoric in shaping commitments and the wider diffusion of technological solutions. The way by which stakeholders manage the technological frames can also be perceived as institutional entrepreneurial process (Henfridsson and Yoo, 2014). Future research will benefit our understanding by examining institutional entrepreneurship in conjunction with 
rhetorical practice and technological frame in the context of technology diffusion.

Third, even though prior accounts (e.g. Huang et al. 2013; Morrison et al. 2013; Sillince 2005) have highlighted the importance of rhetorical congruence, our understanding of how to analytically assess it remains under-developed. By synthesizing some of the key accounts, we are able to establish a conceptual tool, as shown in Figure 1, to address this issue. By individually examining (i) the rhetorical situations articulated by the rhetors, (ii) what the rhetoric strategy was developed (iii) the relationship between rhetorical situation and strategy and (iv) how the audiences responses, we are able to yield an integrative assessment the degree of rhetorical congruence. By mapping the rhetorical situations chronologically, we were able to show how the degree of rhetorical congruence changes over time, or, as in our case, how the lack of congruence was addressed. The degree of rhetorical congruence cannot be judged based simply on how widely a new idea or technology is diffused in a local context, as suggested by Green (2004). It can be equally problematic to assume that accomplishing rhetorical congruence will always lead to positive result, as indicated by Sillince (2005). As shown in our study, even though achieving congruence does not necessarily warrant acceptance and subsequent diffusion, a lack of congruence does not necessarily mean the rejection of a new technology, either. Assessing the degree of congruence helps us to appreciate the relational, emergent and subjective nature of the socio-cognitive process and its impact on the trajectory of technology diffusion. Despite of our contributions, few questions related to the assessment of rhetorical congruence are yet to be addressed. Future research can emphasize on the following questions. For instance, what criterion and frames do the participants deploy to assess technology champions' projected rhetorical situations and rhetorical strategy? How would participants raise their concerns when the degree of congruence is perceived to be low?"

Fourth, this research extends the existing theoretical landscape of the socio-cognitive perspective on technology diffusion by adding an inter-organizational dimension to the analysis. While the influences of external sources have been frequently addressed in the diffusion of new and fashionable managerial practices (e.g., Abrahamson, 1996; Newell et al., 2000), our understanding of how organizations in the same industry collectively make sense of a technological innovation remains limited, albeit that some research has taken place with respect to the perceived usefulness of a technology in relation to internet banking, for example (Cheng, et al., 2006; Lai and $\mathrm{Li}, 2005)$. We extend current thinking on diffusion by providing empirical insights into how stakeholder organizations (in this case, IT vendors, fund houses and competing banks), somewhat discursively it must be said, constructed and negotiated the values, practice and limitations of STP. By spanning our inquiry over a period of nine years, we capture the on-going changes in interpretation as evolving as the rhetorical context evolves. By considering sense-making at the inter-organizational level, we contribute to the current debates by illustrating how uncertainties may be discursively stabilized across organizations, somewhat akin to the "social contagion" notion of Messerschmidt and Hinz (2013).

Fifth, we believe that our approach may also be useful to explore how industry-wide discourse on new information technologies - what Swanson and Ramiller (1997) term 
an organizing vision - may enter and influence the discourse within organizations, thus helping to unpack the phenomenon of technology diffusion. In this regard, we consider this approach adds value to the technology diffusion literature in that it provides an analytical tool to identify the contextual elements that may prove relevant to frame shifts in the early stages of the diffusion process. In particular, future research can investigate how diagnostic and prognostic frames are shaped, understood and absorbed.

In the introductory section of this paper, we made the point that the shared meaning given to the new technology emerges through the social interaction of relevant stakeholders as the diffusion of that technology ensues. We cited some of the recent work on sociomateriality (e.g., Leonardi, 2013; Leonardi and Barley, 2010; Orlikowski, 2007; Orlikowksi and Scott, 2008) in making the point that there is emergence arising from the meaning given to the fusion ${ }^{6}$ of the material artifact and its perceived use, taken together. This is an important point that extends the current debate on sociomateriality (Cecez-Kecmanovic et al. 2014). As with socio-technical systems (Leonardi, 2012), extant research that applies sociomaterial concepts does so in relation to the use and impact of information and communication technologies in and between organizations. Here, we note that such thinking may usefully be extended in relation to the perceived future use of that technology, whether or not the stated rationale for the new technology turns out to be the case or not. Despite the growing interest in the use of sociomaterial concepts in Information Systems research, this line of enquiry may be argued to be at a pre-pubescent stage still. Future research should apply such concepts to technologies pre- and during diffusion in order to yield deeper understandings of how technologies do - or do not - become diffused, and shed further light on the applicability of sociomaterial concepts more widely in our field. For example, new empirical insights may be gained in relation to why it is that organizations (people) accept or reject a particular technology (Leonardi, 2009), and to the, sometimes contradictory, consequences of a new technology (Robey and Boudreau, 1999).

\section{REFERENCES}

Abrahamson, E. 1996. "Management Fashion," Academy of Management Review (21:1), pp. 254-285.

Agarwal, R., and Prasad, J. 1997. "The Role of Innovation Characteristics and Perceived Voluntariness in the Acceptance of Information Technologies," Decision Sciences (28:3), pp. 557-582.

Allen, J.P., and Kim, J. 2005. "IT and the Video Game Industry: Tensions and Mutual Shaping," Journal of Information Technology, (20:4), pp. 234-244.

Barrett, M.I.. 1999. "Challenges of EDI Adoption for Electronic Trading in the London Insurance Market," European Journal of Information Systems (8:1), pp. 115

Benford, R.D., and Snow, D.A. 2000. "Framing Processes and Social Movements: An

\footnotetext{
${ }^{6}$ The term in this context is Orlikowski and Scott's (2008)
} 
Overview and Assessment," Annual Review of Sociology (26:1), pp. 611-639.

Bensaou, M., and Venkatraman, N. 1995. "Configurations of Interorganizational Relationships: A Comparison between U.S. and Japanese Automakers," Management Science (41:9), pp. 1471-1492.

Berente, N., Hansen, S., Pike, J.C., and Bateman, P.J. 2011. "Arguing the Value of Virtual Worlds: Patterns of Discursive Sensemaking of an Innovative Technology," MIS Quarterly. Sep2011, Vol. 35 Issue 3, p685-709.

Billig, M. 1996. Arguing and Thinking: A Rhetorical Approach to Social Psychology. Cambridge: Cambridge University Press.

Bitzer, L.F. 1980. "Functional Communication," In: White, E. (Ed.) Rhetoric in Transition. University Park, PA: Pennsylvania State University Press.

Boh, W.F., Soh, C., and Yeo, S. 2007. "A Case Study of Rosettanet," Communications of the ACM (50:12), pp. 57-62.

Cash, J. I., and Konsynski, B.R. 1985. "IS Redraws Competitive Boundaries," Harvard Business Review, March-April, pp.134-142.

Cecez-Kecmanovic, D., Galliers, R.D., Henfridsson, O., Newell, S., and Vidgen, R. 2014. "The Sociomateriality of Information Systems: Current Status, Future Directions," MIS Quarterly, (38:3), pp. 809-830.

Chau, P. Y. K., and Hui, K. L. 2001. "Determinants of Small Business EDI Adoption: An Empirical Investigation," Journal of Organizational Computing and Electronic Commerce, (11:4), pp. 229-252

Cheney, G., Christensen, L.T., Conrad, C., and Lair, D.J. 2004. "Corporate Rhetoric as Organizational Discourse," In: Grant, D., Hardy, C., Oswick, C., and Putnam, L. (Eds.) Organizational Discourse. London: Sage.

Cheng, E., Lam, D., and Yeung, A. 2006. "Adoption of Internet Banking: An Empirical Study in Hong Kong," Decision Support Systems (42:3), pp. 1558-1572.

Christiaanse, E., and Huigen, J. 1997. "Institutional Dimensions in Information Technology Implementation in Complex Network Settings," European Journal of Information Systems (6:2), pp. 77-85.

Christiaanse, E., and Venkatraman, N. 2002. "Beyond Sabre: An Empirical Test of Expertise Exploitation in Electronic Channels," MIS Quarterly (26:1), pp. 15-38.

Chwelos, P., Benbasat, I., and Dexter, A. S. 2001. "Research Report: Empirical Test of an EDI Adoption Model," Information Systems Research, 12(3), pp. 304-321.

Clemons, E., and Row, M. 1992. "Information Technology and Industrial Cooperation: The Changing Economics of Coordination and Ownership," Journal of Management Information Systems, (9:2), pp. 9-28.

Crable, R.E., and Vibbert, S.L. 1986. "Managing Issues and Influencing Public Policy," Public Relations Review (11:1), pp. 3-16.

Czarniawska-Joerges, B. 1994. "Narratives of Individual and Organizational Identities," In: Deetz, S.A. (Eds.) Communication Yearbook 17. Thousand Oaks, CA: Sage.

Damsgaard, J., and Lyytinen, K. 2001a. "Building Electronic Trading Infrastructures: A Public or Private Responsibility?," Journal of Organizational Computing and Electronic Commerce (11:2), pp. 131-151.

Damsgaard, J., and Lyytinen, K. 2001b. "The Role of Intermediating Institutions in the Diffusion of Electronic Data Interchange (EDI): How Industry Associations Intervened in Denmark, Finland, and Hong Kong," The Information Society (17:3) pp. 195-210. 
Damsgaard, J., and Truex, D. 2000. "Binary Trading Relations and the Limits of EDI Standards: The Procrustean Bed of Standards," European Journal of Information Systems (9:1) pp.173-188.

Davidson, E.J. 2002. "Technology Frames and Framing: A Socio-cognitive Investigation of Requirements Determination," MIS Quarterly (26:4), pp. 329-358.

Davidson, E.J., and Chismar, W.G. 2007. "The Interaction of Institutionally Triggered and Technology-Triggered Social Structure Change: An Investigation of Computerized Physician Order Entry," MIS Quarterly (31:4), pp. 739-758.

Easterby-Smith, M., Thorpe, R., Lowe, A., 1991. Management Research: An Introduction. Sage, London.

Eccles, R.G., Nohria, N., and Berkley, J.D. 1992. Beyond the Hype: Rediscovering the Essence of Management. Harvard Business School Press, Boston.

Erkama, N., and Vaara, E. 2010. "Struggles over Legitimacy in Global Organizational Restructuring: A Rhetorical Perspective on Legitimation Strategies and Dynamics in a Shutdown Case," Organization Studies (31:7), pp. 813-839.

Fairclough, N. 1989. Language and Power. London: Longman.

Galliers, R.D., Markus, M.L., and Newell, S. (eds.) 2007. Exploring Information Systems Research Approaches: Readings and Reflections, London: Routledge.

Galliers, R.D., Swatman, P.M.C., and Swatman, P.A. 1995. "Strategic Information Systems Planning: Deriving Comparative Advantage from EDI," Journal of Information Technology, (10:3), pp. 149-157.

Green, S. 2004. "A Rhetorical Theory of Diffusion," Academy of Management Review (29:4), pp. 653-669.

Grover, V., and Saeed, K. 2007. "The Impact of Product, Market, and Relationship Characteristics on Interorganizational System Integration in Manufacturer-Supplier Dyads," Journal of Management Information Systems (23:4), pp. 185-216

Han, K., Kauffman, R., and Nault, B. 2004. "Information Exploitation and Interorganizational Systems Ownership," Journal of Management Information Systems (21:2), pp.109-135.

Hart, P., and Saunders, C. 1997. "Power and Trust: Critical Factors in the Adoption and Use of Electronic Data Interchange," Organization Science (8:1), pp. 23-42.

Henfridsson, O., and Yoo, Y. 2014. "The Liminality of Trajectory Shifts in Institutional Entrepreneurship," Organization Science, (25:3), pp. 932-950.

Hertwig, M. 2012. "Institutional Effects in the Adoption of e-Business Technology: Evidence from the German Automotive Supplier Industry," Information \& Organization, (22:4), pp. 252-272.

Hsiao, R.L. 2003. "Technology Fears: Distrust and Cultural Persistance in Electronic Marketplace Adoption," Journal of Strategic Information Systems, (12:3), pp. 169199.

Hong, W., and Zhu, K. 2006. "Migrating to Internet-based E-commerce: Factors Affecting E-commerce Adoption and Migration at the Firm Level," Information \& Management, (43: 2), pp. 204-221.

Huang, J., Baptista, J., and Galliers, R.D. 2013. "Reconceptualizing Rhetorical Practices in Organizations: The Impact of Social Media on Internal Communications," Information And Management, (50:2-3), pp. 112-124.

Huang, J., and Galliers, R.D. 2011. "The Importance of Rhetoric in Conceptualising IS Adoption," Journal of Enterprise Information Management, (24:3), pp. 219-223. Iacovou, C.L., Benbasat, I., and Dexter, A.S. 1995. "Electronic Data Interchange and 
Small Organizations: Adoption and Impact of Technology," MIS Quarterly, (19:4), pp. 465-485.

Iskandar, B.Y., Kurokawa, S., and Leblanc, L.J. 2001. "Adoption of Electronic Data Interchange: The Role of Buyer-Supplier Relationships." IEEE Transactions on Engineering Management, (48:4), pp.505-517.

Jarzabkowski, P., Sillince, J., and Shaw, D. 2010. "Strategic Ambiguity as a Rhetorical Resource for Enabling Multiple Interests," Human Relations, (63:2), pp. 219-248.

Kaplan, S. 2008. "Framing Contests: Strategy Making under Uncertainty," Organization Science, (19:5), pp.729-752.

Kauffman, R. J., and Wang, Y.M. 1994. "An Exploratory Econometric Analysis of Shared Electronic Banking Network Adoption," Journal of Strategic Information Systems, (3:1), pp. 61-76.

Klein, H.K., and Myers, M.D. 1999. "A Set of Principles for Conducting and Evaluating Interpretive Field Studies in Information Systems," MIS Quarterly, (23:1), pp. 67-93.

Kroes, M., Chmielarz, P., Chandler, L., Bergler, M., and Smith, B. 2011. "Beyond KOL Management: Communities of Practice as a New Perspective on Pharmaceutical Market Penetration," Journal of Medical Marketing, (11:1), pp.7183.

Kuan, K.K.Y., and Chau, P.Y.K. 2001. "A Perception-Based Model for EDI Adoption in Small Businesses Using a Technology-Organization-Environment Framework," Information \& Management, (38:8), pp. 507-521.

Kumar, K., Dissel, H.G.V., and Bielli, P. 1998. "The Merchants of Prato--Revisited: Toward a Third Rationality of Information Systems," MIS Quarterly, (22:2), pp. 199-226.

Lai, V., and Li, H. 2005. "Technology Acceptance Model for Internet Banking: An Invariance Analysis," Information \& Management, (42:2), pp. 373-386.

Lanzolla, G., and Suarez, F.F. 2012. "Closing the Technology Adoption-Use Divide: The Role of Contiguous User Bandwagon," Journal of Management, (38:3), pp. 836-859.

Lee, A.S., and Baskerville, R.L. 2003. "Generalizing Generalizability in Information Systems Research," Information Systems Research, (14:3), pp. 221-243.

Leonardi, P.M. 2009. "Why Do People Reject New Technologies and Stymie Organizational Changes of Which They Are in Favor? Exploring Misalignments between Social Interactions and Materiality", Human Communication Research, 35(3), 407-441.

Leonardi, P.M. 2012. Materiality, Sociomateriality, and Socio-Technical Systems: What Do These Terms Mean? How Are They Related? Do We Need Them? In P.M. Leonardi, B.A. Nardi, and J. Kallinikos (Eds.), Materiality and Organizing: Social Interaction in a Technological World (pp. 25-48). Oxford: Oxford University Press.

Leonardi, P.M. 2013. "Theoretical Foundations for the Study of Sociomateriality", Information and Organization, 23(2), 59-76.

Leonardi, P.M., and Barley, S.R. 2010. "What's under Construction Here? Social Action, Materiality, and Power in Constructivist Studies of Technology and Organizing. The Academy of Management Annals, 4(1), 1-51.

Lin, A., and Silva, L. 2005. "The Social and Political Construction of Technological Frames," European Journal of Information Systems (14:1), pp. 49-59. 
Mann, A., Kauffman, R.J., Han, K., and Nault, B.R. 2011. "Are There Contagion Effects in Information Technology and Business Process Outsourcing?" Decision Support Systems, (51:4), pp. 64-874.

Messerschmidt, C.M., and Hinz, O. 2013. "Explaining the Adoption of Grid Computing: An Integrated Institutional Theory and Organizational Capability Approach," Journal of Strategic Information Systems, (22:2), pp. 137-156.

Mishra, A.N., and Agarwal, R. 2010. "Technological Frames, Organizational Capabilities, and IT Use: An Empirical Investigation of Electronic Procurement," Information Systems Research (21:2), pp. 249-270.

Moore, G.C., and Benbasat, I. 1991. "Development of an Instrument to Measure the Perceptions of Adopting an Information Technology Innovation," Information Systems Research (2:3), pp. 192-222.

Morrison, Z., Marsden, K., Cresswell, K., Fernando, B., and Sheikh, A. 2013. "Utilizing a Discourse-Based Understanding of Organizational Change to Explore the Introduction of National Electronic Health Records in England," Journal of Change Management, (13:3), pp. 266-282.

Newell, S., Swan, J.A., and Galliers, R.D. 2000. "A Knowledge-focused Perspective on the Diffusion and Adoption of Complex Information Technologies: the BPR Example," Information Systems Journal (10:3), pp. 239-259.

Newman, M., and Robey, D., 1992. "A Social Process Model of User-Analyst Relationships," MIS Quarterly, (16:2), pp. 249-266.

Olesen, K. 2014. "Implications of Dominant Technological Frames Over a Longitudinal Period," Information Systems Journal, (24:3), pp. 207-228.

Orlikowski, W.J. 2000. "Using Technology and Constituting Structures: A Practice Lens for Studying Technology in Organizations," Organization Science (11:4), pp. 404-428.

Orlikowski, W.J. 2007. Sociomaterial Practices: Exploring Technology at Work. Organization Studies, 28(9), 1435-1448.

Orlikowski, W.J., and Gash, D. 1994. "Technological Frames: Making Sense of Information Technology in Organizations," ACM Transaction on Information Systems (12:2), 1994, pp.174-207.

Orlikowski, W.J., and Lacono, C.S. 2001. "Research Commentary: Desperately Seeking the 'IT' in IT Research--A Call to Theorizing the IT Artifact," Information Systems Research (12:2), pp. 121-134.

Orlikowski, W.J., and Scott, S.V. 2008. "Challenging the Separation of Technology, Work and Organization", Academy of Management Annals, 2(1), 433-474.

Pan, S., and Tan, B. 2011. "Demystifying Case Research: A Structured-pragmaticsituational (SPS) Approach to Conducting Case Studies," Information and Organization (21:3), pp.161-176.

Pavlou, P.A. 2002. "Institution-Based Trust in Interorganizational Exchange Relationships: The Role of Online B2B Marketplaces on Trust Formation." Journal of Strategic Information Systems, (11:3-4), pp. 215-243.

Pawlowski, S.D., and Robey, D. 2004. "Bridging User Organizations: Knowledge Brokering and the Work of Information Technology Professionals," MIS Quarterly (28:4), pp. 645-672.

Peppard, J., Galliers, R.D., and Thorogood, A. 2014. "Information Systems Strategy as Practice: Micro Strategy and Strategizing for IS." Journal of Strategic Information Systems, (23:1), pp. 1-10. 
Pozzebon, M., Titah, R., and Pinsonneault, A. 2006. "Combining Social Shaping of Technology and Communicative Action Theory for Understanding rhetorical Closure of IT," Information Technology and People (19:3), pp. 244-271.

Premkumar, G., Ramamurthy, K., and Nilakanta, S. 1994. "Implementation of Electronic Data Interchange: An Innovation Diffusion Perspective," Journal of Management Information Systems, (11:2), pp.157-186.

Premkumar, G., Ramamurthy, K., and Crum, M.R. 1997. "Determinants of EDI Adoption in the Transportation Industry," European Journal of Information Systems, (6:2), pp.107-121

Ramamurthy, K., and Premkumar, G. 1995. "Determinants and outcomes of electronic data interchange diffusion." IEEE Transactions on Engineering Management, (42:4), pp. 332-351.

Ramamurthy, K., Premkumar, G., and Crum, M.R. 1999. "Organizational and Interorganizational Determinants of EDI Diffusion and Organizational Performance: A Causal Model," Journal of Organizational Computing and Electronic Commerce, (9:4), pp.253-285

Riggins, F.J., and Mukhopadhyay, T. 1994. "Interdependent Benefits from Interorganizational Systems: Opportunities for Business Partner Reengineering," Journal of Management Information Systems, (11:2), pp. 37-58.

Robertson, M., Swan, J., and Newell, S. 1996. "The Role of Networks in the Diffusion of Technological Innovation," Journal of Management Studies, (33:3), pp. 333-359.

Robey, D., and Boudreau, M-C. 1999. "Accounting for Contradictory Organizational Consequences of Information Technology: Theoretical Directions and Methodological Implications. Information Systems Research, 10(2), 167-185.

Robey, D., Im, G., and Wareham, J. 2008. "Theoretical Foundations of Empirical Research on Interorganizational Systems: Assessing Past Contributions and Guiding Future Directions," Journal of the Association for Information Systems (9:9), pp. 497-518.

Rodon, J., Pastor, J., Sese, F., and Christiaanse, E. 2008. "Unravelling the Dynamics of IOIS Implementation: An Actor-Network Study of An IOIS in the Seaport of Barcelona," Journal of Information Technology (23:2), pp.97-108

Rodon, J., and Sese, F. 2010. "Analysing IOIS Adoption through Structural Contradictions," European Journal of Information Systems (19:6), pp. 637-648.

Rogers, E.M. 1995. Diffusion of Innovations. New York: The Free Press.

Samutachak, B., and Dekui, L. 2012. "The Effects of Centrality and Prominence of Nodes in the Online Social Network on Word of Mouth Behaviors," Journal of the Academy of Business \& Economics, (12:2), pp. 125-148.

Sia, C.L., Teo, H.H., Tan, B.C.Y., and Wei, K.K. 2004. "Effects of Environmental Uncertainty on Organizational Intention to Adopt Distributed Work Arrangements," IEEE Transactions on Engineering Management (51:3), pp. 253-267.

Sillince, J. 2005. "A Contingency Theory of Rhetorical Congruence," Academy of Management Review (30:3), 2005, pp. 608-621.

Sillince, J., Harindranath, G., and Harvey, C.E. 2001. "Getting Acceptance That Radically New Working Practices Are Required: Institutionalization of Arguments about Change within a Healthcare Organization," Human Relations (54:11), pp. 1421-1454.

Suddaby, R., and Greenwood, R. 2005. "Rhetorical Strategies of Legitimacy," 
Administrative Science Quarterly (50:1), pp. 35-67.

Swan, J., and Newell, S. 1995. "The Role of Professional Associations in Technology Diffusion," Organization Studies (16:5), pp. 847-874.

Swanson, E., and Ramiller, N. 1997. "The Organizing Vision in Information Systems Innovation," Organization Science, (8:5), pp. 458-474.

Teo, H.H., Wei, K.K., and Benbasat, I. 2003. "Predicting Intention to Adopt Interorganisational Linkage: An Institutional Perspective," MIS Quarterly (27:1), pp. 19-49.

Venkatesh, V., Morris, M.G., Davis, G.B., and Davis, F.D. 2003. "User Acceptance of Information Technology: Toward a Unified View," MIS Quarterly (27:3), pp. 425478.

Walsham, G. 1995. "Interpretive Case Studies in IS Research: Nature and Method," European Journal of Information Systems (4:1), pp. 74-81.

Wang, Y., Meister, D.B., and Gray, P.H. 2013. "Social Influence and Knowledge Management Systems Use: Evidence from Panel Data," MIS Quarterly, (37:1), pp. 299-313.

Weick, K. 1995. Sensemaking in Organizations. Sage, London: Sage.

Whittington, R. 2014. "Information Systems Strategy and Strategy-as-Practice: A Joint Agenda," Journal of Strategic Information Systems, (23:1), pp. 87-91.

Wigand, R., Steinfield, C., and Markus, M.L. 2005. "Information Technology Standards Choices and Industry Structure Outcomes: The Case of the U.S. Home Mortgage Industry," Journal of Management Information System (22:2), pp. 165191.

Wu, J.H., and Wang, S.C. 2005. "What Drives Mobile Commerce? An Empirical Evaluation of the Revised Technology Acceptance Model," Information \& Management, (42:5), pp.719-729.

Zaffar, M., Kumar, R., and Zhao, K. 2014. "Impact of Interorganizational Relationships on Technology Diffusion: An Agent-Based Simulation Modelling Approach," IEEE Transactions on Engineering Management, (61:1), pp. 68-79.

Zbaracki, M. 1998. "The Rhetoric and Reality of Total Quality Management," Administrative Science Quarterly (43:3), pp. 602-636. 


\begin{tabular}{|l|l|}
\hline \multicolumn{2}{|c|}{ Table 1: Timeline of STP adoption in Taiwan } \\
\hline Time & Major Event \\
\hline 2000 & STP initiative started to develop in Europe \\
\hline 2003 & Formation of Taiwan Fund Operation Group (TFOG) \\
\hline 2004 & $1^{\text {st }}$ Automation \& Solution Workshop held in Taiwan \\
\hline 2006 & Formation of Asia Fund Automation Consortium \\
\cline { 2 - 2 } & Adoption of STP solution by Innovbank \\
\hline 2007 & Adoption of STP solution by NewTaiwan \\
\hline 2008 & Adoption of STP solution by Leadbank \\
\cline { 2 - 2 } & Adoption of STP solution by Peralbank \\
\cline { 2 - 2 } & Adoption of STP solution by Earthbank \\
\hline
\end{tabular}


Figure 1. Theoretical Frame (adapted from Cheney, et al. 2004 and Kaplan 2008)

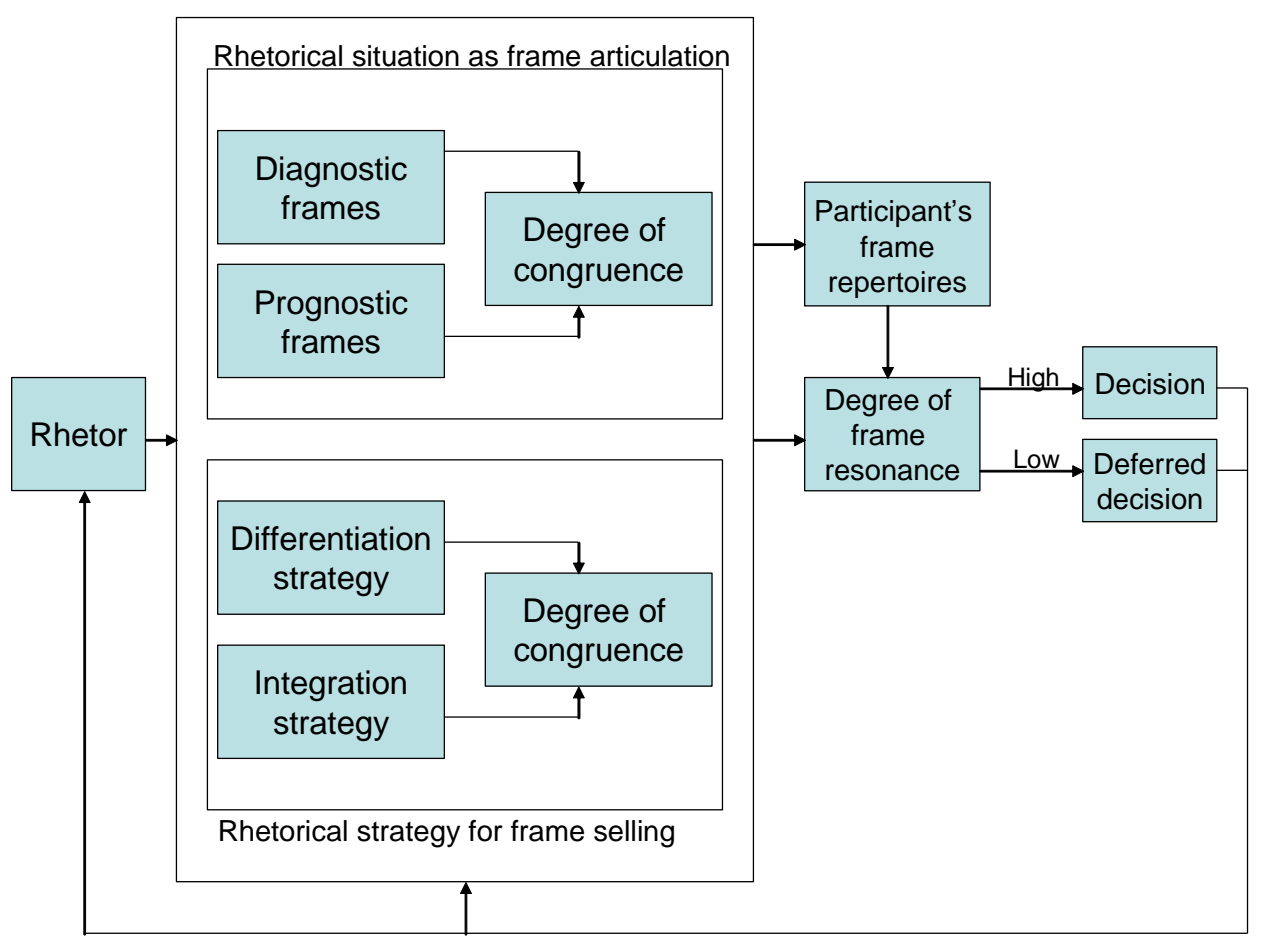

